\title{
Amendment on brain signal intensity on Magnetic Resonance Imaging of asymptomatic HTLV-1 seropositive and HTLV-1 associated myelopathy
}

\author{
Rafael HC Bastos ${ }^{1,3^{*}}$, Luciana C Silva ${ }^{2}$, Débora B Reiss ${ }^{1,3}$, Gabriela S Freitas ${ }^{1,3}$, Mariana A Souza ${ }^{1,3}$, \\ Cláudia LF Horiguchi ${ }^{1,3}$, João GR Ribas ${ }^{3}$, Aline M Silva ${ }^{3}$, Marina L Martins ${ }^{3}$, Anísia da SD Ferreira ${ }^{3}$, Tatiana Martins², \\ Anna Bárbara FC Proietti ${ }^{1,3}$, Luiz CF Romanelli ${ }^{3}$
}

From 16th International Conference on Human Retroviruses: HTLV and Related Viruses Montreal, Canada. 26-30 June 2013

HTLV-1-associated myelopathy (HAM) is a classic neurological disease, but cognitive impairment and altered signal intensity on MRI scans of the brain are described in the literature and suggest a more extensive neurological damage. This is a cross-sectional study, conducted between March $17^{\text {th }}$ and September $28^{\text {th }}, 2012$ in the GIPH cohort, Brazil. HAM was diagnosed on the basis of the World Health Organization diagnostic clinical criteria. MRIs of the brain axial in T1-weighted Flair, fast spinecho T2-weighted fat-suppressed, T2-weighted Flair and diffusion weighted EPI were performed. Blinded interpretation of MRIs was performed by radiologists who did not know clinical neurologic status of the participants. Fazekas scale (0-4) was used to classify the changes in brain signal intensity. In the 120 participants the mean age of the group was $48.0 \pm 12.8$ years (range: 16.4 to 72.6 years), no statistically significant difference between the mean ages of the HAM and asymptomatic groups $(p=0.7)$. Women were 77 (64.2\%) of patients and HAM was diagnosed in 19 (15.8\%). Change of signal intensity at MRIs was observed in $48(47 \%)$ asymptomatic group and 11 (57\%) HAM group $(p=0.4)$. Both groups showed Fazekas evaluation from 0 until 3, without statistically significant differences between them $(p>0.05)$. The alteration of signal intensity on MRIs of the brain of individuals HTLV-1 seropositive asymptomatic and with HAM were not statistically

\footnotetext{
* Correspondence: rhcbastos@hotmail.com

${ }^{1}$ Faculdade da Saúde e Ecologia Humana (FASEH), Vespasiano, Minas Gerais, Brazil

Full list of author information is available at the end of the article
}

significant. As a continuation of this study, we are going to compare these findings with a group of controls without HTLV-1 infection.

\section{Authors' details}

${ }^{1}$ Faculdade da Saúde e Ecologia Humana (FASEH), Vespasiano, Minas Gerais, Brazil. ${ }^{2}$ Medicina Diagnóstica ECOAR, Belo Horizonte, Minas Gerais, Brazil. ${ }^{3}$ Grupo Interdisciplinar de Pesquisa em HTLV (GIPH), Belo Horizonte, Minas Gerais, Brazil.

Published: 7 January 2014

doi:10.1186/1742-4690-11-S1-P10

Cite this article as: Bastos et al:: Amendment on brain signal intensity on Magnetic Resonance Imaging of asymptomatic HTLV-1 seropositive and HTLV-1 associated myelopathy. Retrovirology 2014 11(Suppl 1):P10.

Submit your next manuscript to BioMed Central and take full advantage of:

- Convenient online submission

- Thorough peer review

- No space constraints or color figure charges

- Immediate publication on acceptance

- Inclusion in PubMed, CAS, Scopus and Google Scholar

- Research which is freely available for redistribution

Submit your manuscript at www.biomedcentral.com/submit
C Biomed Central 